\title{
ОРУДНИЙ ПОРІВНЯЛЬНИЙ У КОГНІТИВНО-ОНОМАСІОЛОГІЧНОМУ АСПЕКТІ
}

\author{
ОЛЕНА КРЯЧКО \\ Харківський національний педагогічний університет імені Г.С. Сковороди, Харків - Україна \\ paniolena15@gmail.com; ORCID: 0000-0001-8477-4238
}

\section{NARZĘDNIK PORÓWNAWCZY W ASPEKCIE KOGNITYWNO-ONOMAZJOLOGICZNYM}

\author{
OLENA KRIACZKO \\ Charkowski Narodowy Uniwersytet Pedagogiczny imienia Hryhorija Skoworody, \\ Charków - Ukraina
}

\begin{abstract}
STRESZCZENIE. Artykuł poświęcony jest analizie konstrukcji $\mathrm{z}$ narzędnikiem porównawczym przez pryzmat podejścia kognitywno-onomazjologicznego. Niedostateczny stan badań w tym kierunku warunkuje ich aktualność. Celem pracy jest określenie głównych typów motywacyjnych dla porównania $\mathrm{z}$ nieregularną nieciągłością $\mathrm{i}$ wyjaśnienie specyfiki ich funkcjonowania. Określono ramę modalną narzędnika porównawczego, wyznaczono sytuacje, w których występuje ten przypadek, zdefiniowano mechanizmy powstawania atrybutywnego znaczenia narzędnika porównawczego przyimkowego i przyczasownikowego. Ustalono, że nie wszystkie z motywacyjnych typów są produktywne przy tworzeniu takich porównań. Wskazano obecność szacującego składnika w strukturach o motywacji modalnej, co przyczynia się do wyrażenia wielu subiektywno-modalnych wartości. Określono istotę poznawczą struktur z narzędnikiem porównawczym, w których obserwuje się motywację skojarzeniową. Wymieniono mentalne osobliwości budowy porównania $\mathrm{z}$ narzędnikiem porównawczym (ablativus comparativus).
\end{abstract}

Słowa kluczowe: podejście kognitywno-onomazjologiczne, narzędnik porównawczy, motywacja modalna, motywacja skojarzeniowa 


\title{
COMPARATIVE ABLATIVE IN COGNITIVE AND ONOMASIOLOGICAL ASPECT
}

\section{OLENA KRIACHKO}

H. S. Skovoroda Kharkiv National Pedagogical University, Kharkiv — Ukraine

\begin{abstract}
ABSRACT. The article examines structures with the comparative ablative through the prism of the cognitive and onomasiological approach. The fragmented coverage of the problem determines the topicality of the research. The aim is to identify the main motivation for comparativemes in ablative case and clarify the specificity of their functioning. The modus frame of the ablative comparative is outlined, the situations where this case appears are described, the mechanisms of the origin of the attributive meaning of the ablative comparative case used with nouns and verbs are defined. It is demonstrated that not all motivational types are productive for the formation of such comparatives. The evaluative component is singled out in structures with modus motivation, this promoting a range of subjective and modal meanings. The cognitive nature of ablative comparative structures with associative motivation is elucidated. Mental procedures shaping structures with the ablative comparative case are determined.
\end{abstract}

Key words: cognitive and onomasiological approach, ablative comparative, modus motivation, associative motivation

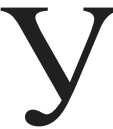

сучасному мовознавстві пріоритетним є вивчення мови як знакового феномена, що відображає пізнавальні мисленнєві процеси та структуру етносвідомості. Фундаментальний аналіз мовної “тканини” на такому рівні неможливий без застосування когнітивно-ономасіологічного аналізу. Його першочергова мета — відстежити механізм мотивації як наскрізного процесу під час номінування лінгвопсихоментальної операції і встановлення семантичної та формальної залежностей між мотиватором i похідною номінативною одиницею (мотивованим знаком) на підставі зв'язків різних компонентів структури знань про позначене. Когнітивно-ономасіологічний аналіз установлює психоментальне підгрунтя формування мовленнєвих структур $з$ огляду на їхній спосіб та причину вибору певних мотиваторів зі структури знань про позначуване, а також на зв’язок цих структур 3 образами, відчуттями, почуттями, емоційно-оцінним компонентом ментально-психонетичного комплексу [див.: Калько 2003].

Порівняння як своєрідне мовне явище досліджували такі вчені: О. Потебня, І. Кучеренко, М. Плющ, І. Вихованець, С. Срмоленко, Н. Сологуб, М. Пилинський, М. Каранська та ін. Українські мовознавці (Л. Ставицька, А. Мойсієнко, В. Забєліна, А. Довженко, С. Рошко, Н. Шаповалова, Л. Прокопчук, 3. Сікорська, К. Буркут, В. Васильченко, О. Марчук та ін.) переважно 3'ясовують семантику й структуру порівнянь, поширених у текстах окремих 
письменників (М. Коцюбинського, О. Чорногуза, Лесі Українки, Т. Шевченка та ін.). Орудний відмінок з огляду на його семантико-граматичні значення й функції досліджували Д. Овсянико-Куликовський, О. Пєшковський, Є. Тимченко, А. Вежбицька, І. Вихованець, Г. Золотова, М. Лукін, Н. Луценко, О. Мельничук, Р. Мразек, О. Панфілов, М. Плющ, А. Романченко, І. Слинько, Г. Судаков, М. Хлєбникова та ін. Більшість розвідок присвячено прагмалінгвістичному та структурно-семантичному аналізу цих конструкцій. Лише невелика кількість досліджень репрезентує той факт, що на когнітивному рівні компаративеми 3 орудним відмінком $є$ способом мовного репрезентування концептуальних реляцій синергетичної системи етносвідомості. Аналіз мотивації номінативних одиниць уможливлює експлікацію цієї системи, вияв психічних процесів, що опосередковують зв'язок мовного й концептуального, процедури отримання, обробляння та переробляння інформації, набутої чуттєво-емпіричним шляхом [Маковецька-Гудзь 2009: 1].

Оперування ментальними репрезентаціями й структурами знань значно полегшує символізація, засобами якої можуть бути й мовні знаки. Дослідники вказують на те, що репрезентації пов'язані з пам'яттю на відсутні в полі зору об'єкти і їхнє просторове розміщення, на схеми дій з ними. За своїм типом вони насамперед є статичними; символізування ж передбачає створення полегшеного ментального “сліду” об' єкта, знака, на місце якого можна підставити весь обсяг знань для цілей когнітивних операцій більш високого рівня. Символ у разі потреби “витягує” з пам'яті саме той обсяг знань, який прагматично необхідний людині в конкретній ситуації [Селіванова 2010: 392]. Семантичні відмінки $є$ універсальними елементами системи смислів кожної мови й можуть бути представленими чи не представленими в морфологічних відмінках різних мов, можуть мати різні можливості мовної репрезентації. Найпростішим 3 низки структурних типів мовних одиниць, що виражають ознаки предметів або дій у зіставленні, уважають орудний порівняльний. Визначальною рисою порівняльних конструкцій з імпліцитним показником $\epsilon$ контамінація образу й показника порівняльних відношень в одній лексемі: образ виражений лексичним значенням слова, а показник - граматичним (формою орудного відмінка). Як зазначає В. Кононенко, компаративеми з орудним відмінком творяться на основі переносних значень слів і гіперболічно виражають характеристику дії. При цьому образне значення послаблюється, але не втрачається. Разом з тим у цій мовній одиниці представлено й момент уподібнення, навіть перетворення [Кононенко 2002: 107]. Беззаперечним видається той факт, що внутрішньою формою й одночасно передумовою порівняльної семантики орудного відмінка є значення суб'єкта, виражене формою орудного відмінка [Луценко 1998: 9]. Усі словоформи, що реалізуються в речення із семантикою орудного порівняльного, набувають оцінного значення, і $є$ характеризувальними [Олексенко 2018: 170]. Розглядаючи подібні словофор- 
ми, А. Романченко зазначає, що, коли орудний порівняльний залежить від іменника, він $\epsilon$ означенням або іменною частиною присудка, і в цьому разі функцію порівняння виконує відмінкова форма [Романченко 2018]. О. Олексенко зауважує, що хоча смисловий акцент припадає на агента порівняння, в основі виникнення такої семантики відмінка все одно лежить предикативно-характеризувальна функція, про яку писав В. Виноградов. Ознака, що лежить в основі метафоричного перенесення й становить ядро предикативно-характеризувального значення, у прямому мотивувальному значенні може бути несуттєвою, може виявлятися як його прихована конотативність $\mathrm{i}$, відповідно, може не відображатися в лексикографічному описі слова. Утворення порівняння в такому разі базується на довгому асоціативному ланцюжку [див.: Олексенко 2018: 2].

Підтримуємо думку О. Рахіліної про те, що орудний порівняльний виникає у двох випадках: 1) у статичній ситуації, коли описується особлива форма об'єкта (при предикаті місця або каузації місця непрямим об'єктом в орудному відмінку виступає ім'я, що позначає об'єкт характерної форми, з якою порівнюється суб'єкт некаузативної пропозиції або об'єкт каузації); 2) у динамічній ситуації, коли описується особливий характер руху (у цьому разі підкреслюється певна якісна характеристика, напр., швидкість чи напрямок). Дослідниця звертає увагу на той факт, що з абстрактними дієсловами, які акцентують результат ситуації й нечутливі до конкретного наповнення окремих iii фаз, орудний порівняльний не вживається [див.: Олексенко 2018: 74]. Це дає можливість розглядати конструкції з орудним порівняльним у контексті теорії Ч. Філлмора, де дієслово займає вторинну, семантично підпорядковану позицію, а його контекст ніби виходить на перший план.

Виразність конструкцій з орудним порівняльним Н. Дев'ятова пояснює і зручністю самої форми (відсутня різка межа між суб'єктом та об'єктом порівняння), і закладеним у ньому образом. Як видається, цей відмінок є особливою синтаксемою, специфічним відмінковим значенням граматичної форми. Складність його вивчення пояснюється тим, що такі ознаки синтаксеми, як значення й функції, не є явними, а можуть бути виявленими лише в результаті системного аналізу. Особливістю орудного порівняльного є орієнтування граматичної форми на передавання видимих ознак, зв'язок із ситуаціями, що можна спостерігати, і неспроможність передати складніші ситуації. Суб' єктне значення відмінка може бути експлікованим з опорою на показники гіпотетичної модальності.

Механізми виникнення атрибутивного значення орудного порівняльного приіменного такі самі, як і обставинного значення орудного порівняльного придієслівного: в основі кожного з них лежить метафоризування як причина адвербіалізування [див.: Олексенко 2018: 71]. Унаслідок різнобічного аналізу вчені встановили ієрархію концептів, відображених у масиві порівнянь, та 
спільні для людського соціуму вершинні поняттєві сфери: 'Людина', 'Природа', 'Суспільство', 'Абстрактні поняття', що конкретизуються у видових варіантах 'Доросла людина', 'Жінка', ‘Дитина', 'Тварини', 'Рослини' тощо [див.: Кононенко 2002: 110].

У цій науковій розвідці увагу сконцентровано на особливостях мотивації структур з орудним порівняльним відмінком. В основі дослідження лежить когнітивно-ономасіологічний підхід О. Селіванової. Зазначена дослідниця визначає мотивацію як „наскрізну [...] психоментальну операцію встановлення семантичної й формальної залежності між мотиватором [твірною основою] і похідною номінативною одиницею (мовним знаком)" на основі різних аспектів „структури знань про позначуване в етнічній свідомості” [Селіванова 2010: 480].

Не всі мотиваційні типи однаково продуктивні для створення компаративем 3 орудним відмінком. У цій науковій студії розглянемо модусний та асоціативний типи мотивації як такі, що найбільш глибоко відображають механізм виникнення структур 3 орудним порівняльним і $\epsilon$ найбільш результативними для їхнього творення.

Модусний тип передбачає „обрання оцінки позначуваного мотиваційною базою ономасіологічної структури й грунтується на різних пізнавальних функціях: сенсорних механізмах інтеріоризації світу, емоційному сприйнятті, мисленнєвій раціональній обробці, образно-метафоричному уподібненні 3 опертям на стереотипи, культурну символіку, архетипи колективного підсвідомого" [Селіванова 2010: 491], порівн.: Віка зачудовано вигнула брови дугою й стала схожа на кумедне звірятко [Печорна 2018], [...] А густа, посріблена борода віником стриміла поверх грудей [Коритко 2018: 38]. Авторка цього дослідження звернула увагу на те, що особливого поширення така мотивація набуває серед конструкцій з орудним порівняльним у приіменному вживанні, хоча придієслівне використання відмінка не усуває модусної мотивації. Як видається, це зумовлено саме прагматичною метою використання таких компаративем та превалюванням їхнього оцінного значення. Такі конструкції за семантикою нагадують ігреми, а, як зазначає О. Халіман, „ігреми виникають як наслідок маніпуляції граматичним значенням відмінка, що змінюе граматичні ознаки слова й сприяє породженню прагматичної оцінної інформації” [Халіман 2013: 42]. Компаративем 3 таким типом мотивації небагато. Це пояснюється „обмеженістю участі відмінка в породженні оцінки через неможливість 'сміливих' транспозицій відмінкових грамем у зв'язку з їхньою вузькою семантичною специфікою” [Халіман 2013: 41].

В аналізованих словосполученнях простежено наявність оцінного компонента в словах конкретної семантики. До цієї групи належать слова, у значеннях яких є оцінки за зовнішністю (губи бантиком; волосся їжаком), уміннями й навичками (руки граблями; ноги буквою $Z$ ), характером (,,Тільки 
душу, дівко, зарання не віддай, бо тоді всі вони свинями стають”, - вперше так сказала мати і похмуро вийшла стелити постелю [Стельмах 2018]), особливостями мови (Вона ледь стримувалася, щуоб і собі не засичати лютою змією [Зінь 2018], Кошовий розливався соловейком [Рибак 2018]). Як бачимо, оцінка в модусно мотивованих порівняльних конструкціях 3 орудним відмінком орієнтується як на логічні судження й властиві денотату характеристики, так і на емоційне ставлення того, хто говорить, до предмета оцінки. Судження та переживання створюють органічну єдність. Такі компаративеми яскраво та емоційно зображують внутрішній світ людини, поведінку, іiі повсякденне життя. Вони призначені для вираження низки суб'єктно-модальних значень.

Асоціативний тип мотивації залежно від донорської та реципієнтної концептосфер у процесі позначення має такі підтипи:

а) структурно-метафоричний, що згідно 3 концепцією Дж. Лакоффа та М. Джонсона, передбачає „перенесення якогось фрагмента концептуальної мережі агента порівняння на концепт референта" [Lakoff 1980: 17]. Базуючись на доборі мотиватора із зони істинної інформації про складники компаративеми, утворюється конструкція, що репрезентує знаки в прямих значеннях. Процес перенесення ознак визначається органічним зв'язком між предметами або класами предметів, порівн.: Голубою стрічкою накручувалась дорога [Стус 2018], Надходить вечір синьою стіною прозорою [Рильський 2018]; Над бором хмари муром [Тичина 2018];

б) дифузно-метафоричний різновид грунтується на розумінні метафоричного механізму як аналогії асоціативних ореолів двох концептів, що створюють комплекс суміжних асоціацій [Калько 2003]. Він пов'язаний з інтеграцією двох концептосфер на підставі асоціативного ореолу, тобто комплексу асоціацій, сформованого нерідко шляхом онтологічного уподібнення сценаріїв [Калько 2003], порівн.: Видно, правда сукровищею набрякла в Леӥній душі [Павленко 2018]; Волосся димом золотим спада на чоло [Рильський 2018]; Пізно увечері впав сніг бинтами бруду на груди [Жадан 2018];

в) гештальтний різновид застосовує мотиватори - знаки інших конщептів - на підставі подібності зорових, слухових, одоративних, тактильних, смакових гештальтів [Селіванова 2018]. Цей тип відображає зв'язок між асоціативно-термінальною частиною ментально-психонетичного комплексу з базовими відчуттями людини та сформованими на їхньому грунті цілісними образами шляхом аналогізування з іншими предметними сферами. При цьому співвідносяться різні сутності, створюючи гештальт з редукованих прототипів, синтезуючи на його основі новий гносеологічний образ, порівн.: Йому пісня в сериі углем горітиме [Метлинський 2018]; Спадає листя на вівтарі - (Кучерявим дзвоном) [Тичина 2018]; Отже, я була для тебе лише грушею, котру гамселять боксери [...]? [Роздобудько 2018]; 
г) архетипний різновид керується кореляцією структури знань про позначене $з$ первісними вродженими психічними елементами, що є виявом родової пам'яті, історичного минулого етносу, людства, їхнього колективного позасвідомого й забезпечують цілісність і єдність людського сприйняття. Механізм такого метафоризування опосередкований складним асоціюванням [Селіванова 2018], порівн.: Він лежав колодою біля воріт два дні і дві ночі [Симоненко 2018]; I в кожній фурі тінями темними ховаються перелякані демони [Жадан 2018]; А від сходу мечами йде гнів! [Тичина 2018].

Асоціативна мотивація поширена у творенні конструкцій з орудним порівняльним через механізм метафоризування, що лежить в основі їхнього виникнення. Проаналізувавши кожен підтип, уважаємо за доцільне процитувати Дж. Лакоффа: „Ми здатні взаємодіяти з об’єктами реального світу, структуруючи їх в опозиції 'частина / ціле', за допомогою сприйняття, що базується на гештальтах, руховій активності та створенні яскравих ментальних образів. Така взаємодія є джерелом доконцептуальної організації нашого досвіду. Наші концепти базового рівня узгоджуються з цією доконцептуальною структурою й осмислюються ії категоріями. Концепти базового рівня мають значно багатшу структуру, ніж кінестетичні образні схеми з грубим окресленням структурних елементів" [Lakoff 1987: 167], тобто компаративеми 3 орудним відмінком висвітлюють процеси індивідуального символьного сприйняття елементів світу й розширюють можливості типових закономірних векторів сприйняття шляхом уведення зіставно несумісних явищ, що належать до різних сфер знання. Спираючись на аналіз цього типу мотивації та погляди Н. Дев’ ятової, робимо висновок про те, що модусна рамка орудного порівняльного відображає перцептивний модус - модус спостереження, що пояснює образотворчу текстову реалізацію конструкцій з орудним порівняльним. Когнітивна сутність цієї моделі - заміщення фрагмента однієї ситуації фрагментом іншої, що й створює особливий ефект ‘способу дії'. Особливість модусної рамки орудного порівняльного пояснює його первинну текстову функцію - образотворчу текстову реалізацію. Орудний порівняльний ситуацію ‘із чим порівнюють’ подає редуковано: з усієї ситуації вибирається тільки фрагмент 'способу дії', і цей фрагмент накладається на вихідну порівнювану ситуацію [Девятова 2008: 47].

Отже, конструкції з орудним порівняльним мають синергетичну системну природу, організовані шляхом взаємної детермінованості різних функційних модулів свідомості, сприяють переведенню інформації різних типів у мовний формат, пов’ язані з асоціативно-термінальним компонентом метафоризованих знаків інших концептів, модусом як оцінним складником, образами, іншими психічними функціями й архетипами колективного позасвідомого. Досліджувані компаративеми є зразком тотальних моделей, що охоплюють безліч найрізноманітніших аспектів аналізованого предмета, містять і компоненти 
фонового мислення, і процедури співвіднесення фігуративного й фонового мислення з невидимим.

Дослідження мотивації в проекції на когнітивні структури колективної свідомості дають змогу (а) простежити можливості інтеріоризування світу, (б) з'ясувати механізми категоризування та концептуалізування емпіричного та внутрішнього рефлексивного досвіду, (в) поглибити знання про семіотичні ресурси природної мови, знакові ресурси ії збагачення та розвитку.

\section{Список використаної літератури}

Арутюнова Н. Д., Типы языковых значений. Оиенка. Событие. Факт, Москва: Наука, 1988.

Девятова Н. М., Творительный сравнения: значение и функиии в тексте, [в:] „Русский язык в школе", 2008, № 10, с. 47-51.

Калько В. В., Когнітивно-ономасіологічний аналіз назв лікарських рослин в украӥнській мові, автореф. дис. ... канд. філол. наук, Одеса 2003.

Кононенко В. І., Синоніміка порівняльних конструкиій, [в:] Мова. Культура. Стиль, зб. наук. ст., Київ-Івано-Франківськ 2002, с. 102-117.

Луценко Н. А., Творительный сравнения: условия реализаиии, исторические и функиионально-смысловые связи, [в:] „Восточноукраинский лингвистический сборник”, 1998, № 4, с. 3-19.

Маковецька-Гудзь Ю. А., Семантичні типи українських художніх порівнянь, [в:] „Мовні та концептуальні картини світу”, 2009, № 26, ч. 2, с. 210-213.

Олексенко О. А., Орудний відмінок із семантикою порівняння в приіменному вживанні, [в:] „Лінгвістичні дослідження”, 2018, № 47, с. 169-175.

Романченко А. П., До питання про компарально-суб'єктні (об'єктні) категоріальні ситуації в прагмалінгвістичному аспекті, [в:] Електронний ресурс: http://dspace.onu.edu.ua:8080/bitstream/1 (15.10.2018).

Селіванова О. О., Когнітивна конщепщія словотворчої мотивації, [в:] Електронний реcypc: http://webcache.googleusercontent.com/search?q=cache:LZ_9vOKVOcEJ:www. selivanova.net/downloads/Cognityvna\%2520concepcia\%2520slovotvor_motyvaciyi. doc $+\& c d=1 \&$ hl $=$ ru\&ct $=$ clnk\&gl=ua $(22.11 .2018)$.

Селіванова О. О., Лінгвістична енциклопедія, Полтава: Довкілля-К, 2010.

Халіман О. В., Категорія відмінка в аспекті аксіологічної прагмалінгвістики, [в:] „Studia Ukrainica Posnaniensia”, 2013, zesz. I, c. 39-45.

Черемисина М. И., Творительный падеж как средство формирования образа, [в:] „Грамматика русского языка", 1972, № 1, с. 72-92.

Lakoff G., Johnson M., Metaphors We Live By, Chicago: University of Chicago Press, 1980. Lakoff G., Women, Fire, and Dangerous Things. What Categories Reveal about the Mind, Chicago: The University of Chicago Press, 1987. 


\section{Spysok vykorystanoi literatury [References]}

Arutyunova N. D., Tipy yazykovyx znachenij. Ocenka. Sobytie. Fakt [Types of Lingual Meaning. Assessment. Event. Fact], Moskva: Nauka, 1988.

Devyatova N. M., Tvoritel'nyj sravneniya: znachenie $i$ funkcii $v$ tekste [Instrumental Comparative: Meaning and Functions in the Text], [v:] „Russkij yazyk v shkole”, 2008, № 10, s. 47-51.

Kalko V. V., Kohnityvno-onomasiolohichnyi analiz nazv likarskykh roslyn v ukrainskii movi [Cognitive-Onomisiological Analysis of Medicinal Plants Denominations in Ukrainian Language], avtoref. dys. ... kand. filol. nauk, Odesa 2003.

Kononenko V.I., Synonimika porivnialnykh konstruktsii [Sunonymy of Comparative Constructions],

[v:] Mova. Kultura. Styl, zb. nauk. st., Kyiv-Ivano-Frankivsk, 2002, s. 102-117.

Lutsenko N. A., Tvoritel'nyj sravneniya: usloviya realizatsii, istoricheskie i funktsional'nosmyslovye svyazi [Instrumental Comparative: Terms of Implementation, Historical and Functional-Semantic Connections], [v:] „Vostochnoukrainskij lingvisticheskij sbornik”, 1998, № 4, s. 3-19.

Makovetska-Hudz Yu. A., Semantychni typy ukrainskykh khudozhnikh porivnian [Semantic Types of Ukrainaian Artistic Comparisons], [v:] „Movni ta kontseptualni kartyny svitu”, 2009, № 26, ch. 2, s. 210-213.

Oleksenko O. A., Orudnyi vidminok iz semantykoiu porivniannia v pryimennomu vzhyvanni [Instrumental Case with Comparative Semantic in Affiliated Usage], [v:] „Linhvistychni doslidzhennia", 2018, № 47, s. 169-175.

Romanchenko A. P., Do pytannia pro komparalno-subiektni (obiektni) katehorialni sytuatsii $v$ prahmalinhvistychnomu aspekti [To the Question of Comparative-Subjective (Objective) Categorical Situations in Pragmalinguistic Aspect], [v:] Elektronnyi resurs: http://dspace. onu.edu.ua:8080/bitstream/1 (15.10.2018).

Selivanova O. O., Kohnityvna kontseptsiia slovotvorchoi motyvatsii [Cognitive Concept of Word-Building Motivation], [v:] Elektronnyi resurs: http://webcache.googleusercontent. com/search?q=cache:LZ_9vOKVOcEJ:www.selivanova.net/downloads/Cognityvna\%252 0concepcia\%2520slovotvor_motyvaciyi.doc $+\& \mathrm{~cd}=1 \& \mathrm{hl}=\mathrm{ru} \& \mathrm{ct}=\mathrm{clnk} \& \mathrm{gl}=\mathrm{ua}(22.11 .2018)$.

SelivanovaO. O., Linhvistychna entsyklopediia [Linguistic Encyclopedia], Poltava: Dovkillia$\mathrm{K}, 2010$.

Khaliman O. V., Katehoriia vidminka vaspekti aksiolohichnoi prahmalinhvistyky [The Category of Case in Axiological Pragmalinguistics], [v:] „Studia Ukrainica Posnaniensia”, 2013, zesz. I, s. 39-45.

Cheremisina M. I., Tvoritel'nyj padezh kak sredstvo formirovaniya obraza [Instrumental Case as a Way of Figure Formation], [v:] „Grammatika russkogo yazyka”, 1972, № 1, s. 72-92.

Lakoff G., Johnson M., Metaphors We Live By, Chicago: The University of Chicago Press, 1980. Lakoff G., Women, Fire, and Dangerous Things. What Categories Reveal about the Mind, Chicago: The University of Chicago Press, 1987. 


\section{Список використаних джерел}

Жадан С., Генерал Юда, [в:] Електронний ресурс: https://ukrlit.net/lib/zhadan/2.html (29.06.2018).

Жадан С., Час, [в:] Електронний ресурс: https://nashe.com.ua/song/28993 (12.10.2018).

Зінь 3., Справи земні, [в:] Електронний ресурс: https://www.litres.ru/zoryana-z-n/spravizemn/chitat-onlayn/ (04.10.2018).

Коритко Р., Брати рогатиниі, Львів: Червона калина, 1999.

Метлинський А., Зрадник, [в:] Електронний ресурс: https://www.myslenedrevo.com.ua/uk/ Lit/M/MetlynskyA/Verses/Zradnyk.html (13.05.2018).

Павленко М., Санта Лючія в кирзових чоботях, [в:] Електронний ресурс: https://www. chasipodii.net/article/2299/?vsid=fc5ad465d33eab109de6107 (23.04.2018).

ПечорнаО., Фортеця длясерия,[в:]Електроннийресурс:https://www.livelib.ru/book/64049/ readpart-fortetsya-dlya-sertsya-olena-pechorna/ 6 (23.09.2018).

Рибак Н., Переяславська рада, [в:] Електронний ресурс: https://www.ereading.club/book. php?book=49547 (02.02.2018).

Рильський М., Надходить вечір синьою стіною, [в:] Електронний ресурс: http://chtyvo. org.ua/authors/Rylskyi_Maksym/(29.01.2018).

Рильський М., Волосся димом золотим спада на чоло, [в:] Електронний ресурс: http:// chtyvo.org.ua/authors/Rylskyi_Maksym/ (29.01.2018).

Роздобудько I., Дванадиять, або Виховання жінки в умовах, не придатних до життя, [в:] Електронний ресурс: http://ukrclassic.com.ua/katalog/r/rozdobudko-iren/477-irenrozdobudko-dvanadtsyat-abo-vikhovannya-zhinki-v-umovakh-ne-pridatnikh-do-zhittya? ?start=22 (10.11.2018).

Симоненко В., Бенкет на току, [в:] Електронний ресурс: http://www.ukrcenter.com/Лiтeратура/Василь-Симоненко/21077-7/Вино-з-троянд (19.09.2018).

Стельмах М., Гуси-лебеді летять, [в:] Електронний ресурс: https://www.ukrlib.com.ua/ books/printit.php?tid=323 (19.08.2018).

Стус В., Вже котрий це до тебе лист, [в:] Електронний pecypc: http://litmisto.org. $\mathrm{ua} / \mathrm{p}=23211(15.04 .2018)$.

Тичина П., Туман, [в:] Електронний ресурс: http://ukrlit.org/tychyna_pavlo_hryhorovych/ enharmoniine (20.12.2018).

\section{Spysok vykorystanykh dzherel}

Zhadan S., Heneral Yuda [Yuda, the General], [v:] Elektronnyi resurs: https://ukrlit.net/lib/zhadan/2.html (29.06.2018).

Zhadan S., Chas [Time], [v:] Elektronnyi resurs: https://nashe.com.ua/song/28993 (12.10.2018).

Zin Z., Spravy zemni [The Earthly Matters], [v:] Elektronnyi resurs: https://www.litres.ru/zoryana-z-n/spravi-zemn/ chitat-onlayn/ (04.10.2018).

Korytko R., Braty rohatyntsi [Rogatyntsi Brothers], Lviv: Chervona kalyna, 1999. 
Metlynskyi A., Zradnyk [The Betrayer], [v:] Elektronnyi resurs: https:// www.myslenedrevo. com.ua/uk/Lit/M/MetlynskyA/Verses/Zradnyk.html (13.05.2018).

Pavlenko M., Santa Liuchiia v kyrzovykh chobotiakh [Santa Luchia in Tarpaulin Boots], [v:] Elektronnyi resurs: https://www. chasipodii.net/article/2299/?vsid=fc5ad465d33eab109de6107 (23.04.2018).

Pechorna O., Fortetsia dlia sertsia [A Fortress for Heart], [v:] Elektronnyi resurs: https://www.livelib.ru/book/64049/ readpart-fortetsya-dlya-sertsya-olena-pechorna/ 6 (23.09.2018).

Rybak N., Pereiaslavska rada [Pereyaslav Council], [v:] Elektronnyi resurs: https://www.ereading.club/book. php?book=49547 (02.02.2018).

Rylskyi M., Nadkhodyt vechir synoiu stinoiu [The Evening is Coming as a Blue Wall], [v:] Elektronnyi resurs: http://chtyvo.org.ua/ authors/Rylskyi_Maksym/ (29.01.2018).

Rylskyi M., Volossia dymom zolotym spada na cholo [Hair Falls on the Forehead as Golden Smoke], [v:] Elektronnyi resurs: http://chtyvo.org.ua/ authors/Rylskyi_Maksym/ (29.01.2018).

Rozdobudko I., Dvanadtsiat, abo Vykhovannia zhinky v umovakh, ne prydatnykh do zhyttia [Twelve or Education of a Woman in Conditions Unsuitable for Life], [v:] Elektronnyi resurs: http://ukrclassic.com.ua/katalog/r/rozdobudko-iren/477-iren-rozdobudko-dvanadts yat-abo-vikhovannya-zhinki-v-umovakh-ne-pridatnikh-do-zhittya?start=22 (10.11.2018).

Symonenko V., Benket na toku [A Feast in the Barnyard], [v:] Elektronnyi resurs: http:// www.ukrcenter.com/ Literatura/ Vasyl- Symonenko/ 21077-7/ Vyno- z- troiand (19.09.2018).

Stelmakh M., Husy-lebedi letiat [Geese-Swans were Flying], [v:] Elektronnyi resurs: https://www.ukrlib.com.ua/books/ printit.php?tid=323 (19.08.2018).

Stus V., Vzhe kotryi tse do tebe lyst [Another Letter to You], [v:] Elektronnyi resurs: http://litmisto.org.ua/?p=23211 (15.04.2018).

Tychyna P., Tuman [Fog], [v:] Elektronnyi resurs: http://ukrlit.org/tychyna_pavlo_hryhorovych/ enharmoniine (20.12.2018). 